\title{
FAKTOR - FAKTOR YANG BERHUBUNGAN DENGAN PERILAKU SEKS BEBAS PADA REMAJA KELAS II DI SMKS 4 PGRI KOTA BENGKULU
}

\author{
The Factors Related to Free Sex Behaviour on Adolescent Class II \\ in SMKS 4 PGRI Bengkulu
}

\author{
Tria Nopi Herdiani ${ }^{1}$, Awal Isgiyanto ${ }^{2}$, Wiwit Novitaria ${ }^{1}$

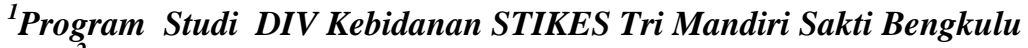 \\ ${ }^{2}$ Program Studi Matematika FMIPA Universitas Bengkulu \\ Email : direja.mandira1415@gmail.com
}

\begin{abstract}
ABSTRAK
Pergaulan bebas di kalangan remaja akhir-akhir ini meningkat. Setiap tahun terjadi kehamilan diluar nikah akibat perilaku sek bebas yang mengakibatkan remaja melakukan aborsi yang tidak aman (unsafe abortion). Penelitian ini bertujuan untuk mengetahui faktor - faktor yang berhubungan dengan perilaku seks bebas pada remaja kelas II di SMKS 4 PGRI Kota Bengkulu.Penelitian ini menggunakan desain deskriptif korelasi dengan pendekatan cross sectional. Populasi sebanyak 68 siswa, sampel diambil seluruh dari jumlah populasi yaitu 68 siswa. Pengambilan data ditentukan secara total sampling. Pengambilan data mencakup data primer dan sekunder yang dikumpulkan pada bulan Juli 2016 dengan instrumen berupa lembar kuesioner. Hasil penelitian didapatkan : terdapat 52 responden (76,5\%) memilik perilaku seks ringan, 42 responden $(61,8 \%)$ berpengetahuan baik tentang perilaku seks bebas, 51 responden $(75,0 \%)$ menggunakan sosial media dengan baik. 46 responden $(67,6 \%)$ memiliki peran keluarga dengan baik, dan ada hubungan antara pengetahuan tentang perilaku seks bebas, social media, dan peran keluarga terhadap perilaku seks bebas pada siswa kelas II di SMKS 4 PGRI Kota Bengkulu dengan kategori sangat kuat.
\end{abstract}

Kata Kunci : pengetahuan, peran keluarga, perilaku seks bebas, sosial media

\begin{abstract}
Free sex in adolescent is improving in every year experienced unwanted pregnancy because of free sex so that they are doing unsafe abortion. This research aimed to identify what factors were related to sex behaviour with adolescent in class II SMKS 4 PGRI Bengkulu. This research used a descriptive correlation design with cross sectional approach. Population counted 68 students, sample was taken the whole of the population of 68 students. Data retrieval was determined by total sampling. Collecting data included primary and secondary data were collected in July 2016, with the instrument in the form of questionnaire.The Result of this research showed that: there was 52 respondents (76,5\%) had mild sexual behaviour, 42 respondents (61,8\%) had a good
\end{abstract}


knowledge about free sex, 51 respondents (75,0\%) used social media well, 46 respondents $(67,6 \%)$ got family roles well, and there was a relationship between knowledge about free sex behaviour, social media, and family roles on adolescent Class II in SMKS 4 PGRI Bengkulu with a very strong category.

Keywords : free Sex Behavior, knowledge, social media, role of the family

\section{A. Pendahuluan}

Menurut Subakthi (2009), remaja merupakan masa peralihan antara tahap anak dan dewasa yang jangka waktunya berbeda-beda tergantung faktor sosial dan budaya. Cirinya adalah alat reproduksi mulai berfungsi, libido mulai muncul, intelegensi mencapai puncak perkembangannya, emosi sangat labil, kesetiakawanan yang kuat terhadap teman sebaya dan belum menikah. Kondisi yang belum menikah menyebabkan remaja secara sosial budaya termasuk agama dianggap belum berhak atas informasi dan edukasi apalagi pelayanan medis untuk kesehatan reproduksi. Terjerumusnya remaja ke dalam dunia hubungan sosial yang luas maka mereka tidak saja harus mulai adaptasi dengan norma perilaku sosial tetapi juga sekaligus dihadapkan dengan munculnya perasaan dan keinginan seksual.

Setiap tahun terdapat 210 juta remaja yang hamil di seluruh dunia. Dari angka tersebut, 46 juta di antaranya melakukan aborsi yang diakibatkan karena terlalu nafsu birahi selama pacaran. Akibatnya terdapat 70.000 kematian remaja akibat melakukan aborsi tidak aman sementara empat juta lainnya mengalami kesakitan dan kecacatan. WHO (2010) juga memperkirakan ada 20 juta kejadian aborsi tidak aman (unsafe abortion) di dunia, 9,5\% (19 dari 20 juta tindakan aborsi tidak aman) diantaranya terjadi di negara berkembang. Sekitar $13 \%$ dari total remaja yang melakukan aborsi tidak aman berakhir dengan kematian dan rata-rata $100 \%$ seluruh remaja yang ada di dunia, diperkirakan $47 \%$ nya telah terlibat dalam prilaku seks bebas.

Menurut Hidayat dalam Tinceuli (2010), di Indonesia diperkirakan ada 1 juta remaja yang mengalami kehamilan di luar nikah, sedangkan di seluruh dunia diperkirakan 15 juta remaja setiap tahunnya hamil, $60 \%$ di antaranya hamil di luar nikah. Dari beberapa penelitian menyebutkan salah satu penyebab kehamilan di luar nikah adalah ketidakmampuan remaja mengendalikan dorongan biologis.

Kartono (2008) mengungkapkan bahwa pergaulan bebas di kalangan remaja yang akhir-akhir ini terjadi adalah karena remaja mencari pengetahuan dan informasi tentang seksualitas sendiri lewat teman yang sama-sama belum tahu akibat seks bebas, majalah-majalah porno, video, dan tempat hiburan malam yang memberikan akses informasi tanpa sensor sehingga proses kematangan alat reproduksi pada remaja tidak diimbangi dengan informasi yang baik. Berbagai cara pencegahan kehamilan yang sangat mudah dilakukan, seperti pemasaran alat kontrasepsi di masyarakat luas, adanya tempat aborsi dengan tenaga ahli medis yang dianggap aman, dan adanya anggapan bahwa kalau hanya melakukan hubungan seks satu kali tidak akan terjadi kehamilan dan tertular penyakit kelamin membuat remaja tidak takut terhadap dampak negatif dari perilaku seks bebas. Anak dari keluarga baikbaik, dengan pendidikan agama sejak 
kecil, dan penanaman moral, serta pemberian pengertian tentang normanorma sekalipun sekarang tidak dapat langsung menjamin bahwa anak akan dengan otomatis menjadi remaja yang bisa bersikap dan berperilaku baik.

Remaja berusaha menemukan jawaban atas kekaburan identitas itu melalui kelompok sosial di luar keluarga, yaitu kelompok teman sebaya (peer group). Teman sebaya memainkan peranan yang penting dalam perkembangan psikologis dan sosial sebagian besar remaja. Hal ini karena remaja tidak mengetahui cara bergaul dengan kawan-kawan dan orang dewasa lainnya, dan cara-cara yang dibutuhkan untuk menarik hati kawan-kawannya. Menurut Mussen (2007), kelompok inilah yang merupakan bagian integral dari identitas sosial individu. Dengan interaksi tersebut memberikan kesempatan pada remaja untuk belajar bagaimana mengendalikan perilaku sosial, mengembangkan minat yang sesuai dengan usia, dan berbagi masalah dan perasaan bersama. Pada masa ini remaja cenderung konform dan mengikuti sikap atau perilaku kelompoknya. Bersama kelompoknya, remaja merasa menemukan identitas dan berharap tidak mengalami penolakkan dengan konformitasnya tersebut. Dalam masa ini orang tua perlu menyadari bahwa keluarga juga merupakan bagian integral identitas sosial setiap anggotanya. Para orang tua harus sadar, bahwa banyak dari bagian kehidupan remaja yang sulit untuk dibagi bersama orang tua, jika tidak maka mungkin orang tua akan mengalami kesulitan untuk memahami masalah remaja meskipun mereka berusaha dan benar-benar memperhatikan kesejahteraan anak mereka.
Pentingnya menjaga remaja untuk berperilaku seksual secara sehat adalah karena dalam perkembangannya, remaja belum begitu memahami tentang dampak perilaku seksual yang beresiko, apalagi rasa keingintahuan remaja mengenai seksual terhitung tinggi. Penyalahgunaan teknologi yang terjadi pada saat-saat ini, misalnya maraknya peredaran film / video porno, majalah porno dapat memberikan pengaruh negatif pada perkembangan remaja apalagi bila tidak didukung dengan ketersediaan informasi yang benar mengenai perilaku seksual yang sehat dan aman baik melalui berbagai media yang ada maupun perhatian orangorang terdekatnya (Rahman, 2012).

Tingginya angka Kehamilan Tidak Dikehendaki (KTD), korban unsafe abortion, meningkatnya Infeksi Menular Seksual (IMS), HIV/AIDS diantaranya adalah karena ketidaktahuan remaja akibat tidak ada informasi bertanggung jawab mengenai reproduksi sehat. Perilaku seksual remaja yang cenderung meningkat tanpa adanya akses informasi yang memadai mengenai seks, seksual, dan kesehatan reproduksi ini perlulah kiranya dicarikan jalan penyelesaian salah satunya melalui jalur pendidikan (Kedaulatan Rakyat, 2007).

Faktor penyebab perilaku seks bebas pada remaja adalah pengetahuan, kurangnya pengetahuan tentang kesehatan reproduksi pada remaja yang sudah mulai berkembang kematangan seksualnya secara lengkap jika kurang mendapat pengarahan dari orang tua khususnya tentang akibat-akibat perilaku seks bebas, maka akan berdampak negatif, dan akan sulit untuk mengendalikan rangsanganrangsangan, seperti meningkatnya libido seksual. Selain pengetahuan faktor lainnya yaitu norma agama, 
orang tua, pergaulan semakin bebas, dan media informasi. Banyak kesempatan pornografi melalui media massa yang membuat mereka melakukan perilaku seksual secara bebas tanpa mengetahui resiko-resiko yang dapat terjadi misalnya kehamilan yang tidak diinginkan (Sarwono, 2011).

Menurut penelitian Sebayang (2010) hubungan seks bebas bisa terjadi karena imbalan dan dorongan dari pikiran. Hubungan seks bukan karena tempat itu ada, tapi karena persetubuhan itu sudah ada dipikirannya untuk dilakukan. Hubungan seks itu dilakukan sebagai imbalan dari kebaikan yang diberikan pacar. Hal itu terjadi karena remaja putri mengalami tekanan-tekanan yang mereka dapatkan di rumah, orang tua yang tidak memperhatikan anaknya yang seharusnya perhatian dan ketenangan mereka dapatkan dari rumah dan orang tua. Pacar yang mereka jadikan sebagai tempat sandaran dan sumber kenyamanan untuk mengatasi tekanan-tekanan yang mereka rasakan malah membawa mereka ke kehidupan yang tidak sewajarnya, mengajarkan mereka sesuatu yang seharusnya belum mereka ketahui. Dalam konteks berpacaran, imbalan menjadi sesuatu hal atau temuan yang baru.

Rohmawati (2008) dalam Damarsih (2011) mengatakan bahwa remaja yang terjerumus kedalam pergaulan bebas kebanyakan dari keluarga yang bercerai atau pernah bercerai dan keluarga dengan banyak konflik serta perpecahan. Hubungan orang tua yang harmonis akan menumbuhkan kehidupan emosional yang optimal terhadap perkembangan kepribadian anak. Orang tua yang sering bertengkar akan menghambat komunikasi dalam keluarga, serta anak akan melarikan diri (menjauh) dari keluarganya. Keluarga yang tidak lengkap misalnya karena perceraian atau kematian, serta keluarga dengan ekonomi yang kurang, dapat mempengaruhi perkembangan jiwa anak.

Ketua Jaringan Peduli Perempuan dan Anak (JPPA) Jawa Tengah, Widanti (2011) mengatakan bahwa jumlah siswi yang hamil akan terus meningkat, tercermin dari penelitiannya pada sekolah jenjang SMP dan SMA tahun 2010 yang menunjukkan dalam tiap sekolah ratarata ditemukan empat hingga tujuh siswa yang hamil, bahkan pada tahun tersebut kenaikannya 10\% hingga $15 \%$.

Kementerian Kesehatan Republik Indonesia (2010) mengungkapkan bahwa dari 1189 remaja belum menikah (berusia 13-19 tahun) di Jawa Barat dan 922 remaja di Bali, ditemukan $7 \%$ remaja perempuan di Jawa Barat dan 5\% di Bali mengakui pernah mengalami kehamilan.

Sirait selaku Ketua Komnas Perlindungan Anak dalam Forum Diskusi Anak Remaja (2011), menemukan bahwa remaja yang melakukan seks pranikah kebanyakan diusia 15 tahun. Data tersebut ditemukan dengan mengumpulkan 14.726 sampel anak SMP dan SMA di 12 kota besar di Indonesia, antara lain Jakarta, Bandung, Makassar, Medan, Lampung, Palembang, Kepulauan Riau dan kota-kota di Sumatera Barat. Ditemukan juga sebanyak 21 persen remaja atau satu diantara lima remaja di Indonesia pernah melakukan aborsi. Mereka mengaku hampir 93,7 persen pernah melakukan hubungan seks, 83 persen mengaku pernah menonton video porno, dan 21,2 persen mengaku pernah melakukan aborsi (Sirait, 2011).

Data dari SMKS 4 PGRI, jumlah murid di SMKS 4 PGRI tahun 2015 
yaitu sebanyak 174 orang. Terdiri dari kelas I sebanyak 26 siswa dan 35 siswi, kelas II sebanyak 20 siswa dan 48 siswi, kelas III sebanyak 13 siswa dan 32 siswi.

Rumusan masalah dalam penelitian ini adalah " Apa saja faktorfaktor yang berhubungan dengan perilaku sek bebas pada remaja kelas II di SMKS 4 PGRI Kota Bengkulu “. Tujuan penelitian ini adalah untuk mengetahui faktor - faktor yang berhubungan dengan perilaku seks bebas pada remaja kelas II di SMKS 4 PGRI Kota Bengkulu.

\section{B. Metode Penelitian}

Penelitian ini dilakukan di di SMKS 4 PGRI Kota Bengkulu pada bulan Juli 2016. Jenis penelitian ini adalah survey analitik dengan desain cross sectional. Populasi penelitian ini yaitu siswa kelas II SMKS 4 PGRI berjumlah 68 siswa. Jumlah sampel sebanyak 68 responden. Teknik pengambilan sampel total sampling. Variabel terikat yang diteliti adalah perilaku sek bebas dan variabel bebas yaitu pengetahuan, sosial media, dan peran keluarga. Jenis data yang digunakan dalam penelitian ini adalah data primer dan data sekunder. Data primer diperoleh dengan kuesioner. Data dianalisis secara analisis univarit dan analisis bivariat. Uji statistik yang digunakan adalah uji chi-square $\left(\chi^{2}\right)$. Untuk mengetahui keeratan hubungan digunakan contingency coefficient (C).

\section{Hasil Penelitian}

\section{Analisis Univariat}

Analisis univariat dilakukan untuk melihat distribusi frekuensi faktor-faktor yang mempengaruhi perilaku seks bebas pada remaja kelas II di SMKS 4 PGRI Kota Bengkulu.

Tabel 1

Distribusi Frekuensi Perilaku Seks Bebas pada Remaja Kelas II di SMKS 4 PGRI Kota Bengkulu

\begin{tabular}{clcc}
\hline No & Perilaku Seks Bebas & Frekuensi & Persentase $(\%)$ \\
\hline 1 & Berat & 16 & 23,5 \\
2 & Ringan & 52 & 76,5 \\
& Jumlah & 68 & 100 \\
\hline
\end{tabular}

Berdasarkan Tabel 1 dapat perilaku sek bebas tingkat berat dan 52 diketahui bahwa dari 68 responden, responden (76,5\%) memiliki perilaku sek terdapat 16 responden $(23,5 \%)$ memiliki bebas tingkat ringan.

Tabel 2

Distribusi Frekuensi Pengetahuan Seks Bebas pada Remaja Kelas II di SMKS 4 PGRI Kota Bengkulu

\begin{tabular}{clcc}
\hline No & Pengetahuan & Frekuensi & Persentase $(\%)$ \\
\hline 1 & Kurang & 16 & 23,5 \\
2 & Cukup & 10 & 14,7 \\
3 & Baik & 42 & 61,8 \\
& Jumlah & 68 & 100,0 \\
\hline
\end{tabular}

Berdasarkan Tabel 1 dapat dilihat bahwa dari 68 responden, terdapat 16 responden $(23,5 \%)$ berpengetahuan kurang, $\quad 10$ responden $\quad(14,7 \%)$ berpengetahuan cukup, dan 42 responden $(61,8 \%)$ berpengetahuan baik. 
.Tabel 3

Distribusi Frekuensi Penggunaan Sosial Media pada Remaja

Kelas II di SMKS 4 PGRI Kota Bengkulu

\begin{tabular}{clcc}
\hline No & $\begin{array}{c}\text { Penggunaan Sosial } \\
\text { Media }\end{array}$ & Frekuensi & Persentase (\%) \\
\hline 1 & Kurang Baik & 17 & 25,0 \\
2 & Baik & 51 & 75,0 \\
& $\quad$ Jumlah & 68 & 100,0 \\
\hline
\end{tabular}

Berdasarkan Tabel 3 dapat menggunakan sosial media kurang baik diketahui bahwa dari 68 responden, dan 51 responden $(75 \%)$ menggunakan terdapat 17 responden $(25 \%)$ sosial media baik.

Tabel 4

Distribusi Frekuensi Peran Keluarga Pada Remaja

Kelas II di SMKS 4 PGRI Kota Bengkulu

\begin{tabular}{cccc}
\hline No & Peran Keluarga & Frekuensi & Persentase (\%) \\
\hline 1 & Kurang Baik & 22 & 32,4 \\
2 & Baik & 46 & 67,6 \\
& Jumlah & 68 & 100,0 \\
\hline
\end{tabular}

Berdasarkan Tabel 4 dapat diketahui bahwa dari 68 responden, terdapat 22 responden $(32,4 \%)$ peran keluarga kurang baik dan 46 responden $(67,6 \%)$ peran keluarga baik.

\section{Analisis Bivariat}

Analisis bivariat bertujuan untuk mengetahui hubungan antara variabel bebas (pengetahuan, sosial media, peran keluarga) dengan variabel terikat (perilaku sek bebas). Hasil dari analisis bivariat dapat dilihat dari tabel berikut ini:.

Tabel 5

Hubungan Pengetahuan dengan Perilaku Seks Bebas pada Remaja

Kelas II di SMKS 4 PGRI Kota Bengkulu

Perilaku Seks Bebas

\begin{tabular}{lccccccccc}
\multirow{2}{*}{ Pengetahuan } & \multicolumn{2}{c}{ Berat } & \multicolumn{2}{c}{ Ringan } & Total & $\%$ & $\chi^{2}$ & $p$ & $C$ \\
& $\mathrm{~N}$ & $\%$ & $\mathrm{~N}$ & $\%$ & & & & & \\
\hline Kurang & 13 & 19,1 & 3 & 4,4 & 16 & 23,5 & & & \\
Cukup & 3 & 4,4 & 7 & 10,3 & 10 & 14,7 & 42,782 & 0,000 & 0,621 \\
Baik & 0 & 0,0 & 42 & 61,8 & 42 & 61,8 & & & \\
Jumlah & 16 & 23,5 & 52 & 64,8 & 68 & 100,0 & & & \\
\hline
\end{tabular}

Tabulasi silang antara berperilaku seks ringan sebanyak 42 pengetahuan dengan perilaku seks responden $(61,8 \%)$, responden yang bebas. Dari tabel tersebut diperoleh berpengetahuan cukup dari 10 bahwa responden yang berpengetahuan responden 3 responden $(4,4 \%)$ baik tidak ada yang memiliki perilaku memiliki perilaku seks berat dan 7 seks bebas berat namun yang responden $(10,3 \%)$ memiliki perilaku 
seks ringan, sedangkan responden yang memiliki pengetahuan kurang, dari 16 responden terdapat 13 responden $(19,1 \%)$ memiliki perilaku seks bebas berat dan 3 responden $(4,4 \%)$ memiliki perilaku seks ringan.

Dari hasil uji Chi-square $\left(X^{2}\right)$, karena tidak ada nilai expected yang kurang dari 5 maka diperoleh nilai continuity correction 42,782 dan nilai $P$ Value $=0,000<\alpha=0,05$ berarti signifikan. Jadi Ho ditolak dan $\mathrm{Ha}$ diterima. Kesimpulannya ada hubungan yang signifikan antara pengetahuan tentang seks bebas dengan perilaku seks bebas pada remaja kelas II SMKS 4 PGRI Kota Bengkulu tahun 2016.

Hasil uji contingency coefficient pada tabel diatas didapat nilai $\mathrm{C}=0,621$ dengan approx.sig.= $0.000 \leq 0.05$ berarti signifikan. Nilai $\mathrm{C}$ tersebut dibandingkan dengan nilai $\mathrm{C}_{\max }=\sqrt{ } \frac{m-1}{m}$ dimana $m$ adalah nilai terkecil dari baris atau kolom. Nilai $\mathrm{C}_{\max }=\sqrt{ } \frac{2-1}{2}=0.707$. Karena nilai $\mathrm{C}=$ 0.621 sangat dekat dengan nilai $\mathrm{C}_{\max }=$ 0.707 , maka kategori hubungan sangat kuat.

Tabel 6

Hubungan Sosial Media Dengan Perilaku Seks Bebas pada Remaja Kelas II di SMKS 4 PGRI Kota Bengkulu

\begin{tabular}{lccccccccc}
\hline \multicolumn{1}{c}{ Perilaku Seks Bebas } \\
\multicolumn{1}{c}{ Berat } & \multicolumn{2}{c}{ Ringan } & & & & & \\
Sosial & $\mathrm{N}$ & $\%$ & $\mathrm{~N}$ & $\%$ & Total & $\%$ & $\chi^{2}$ & $p$ & $C$ \\
Media & & & & & & & & & \\
\hline Kurang & 16 & 23,5 & 1 & 1,5 & 17 & 25,5 & & & \\
Baik & & & & & & & 62,769 & 0,000 & 0,693 \\
Baik & 0 & 0,0 & 51 & 75,0 & 51 & 75,5 & & & \\
Jumlah & 16 & 23,5 & 52 & 76,5 & 68 & 100,0 & & & \\
\hline
\end{tabular}

Tabulasi silang antara penggunaan sosial media dengan perilaku seks bebas. Dari tabel tersebut diperoleh dari 51 responden yang menggunakan sosial media dengan baik seluruhnya $(75,0 \%)$ memiliki perilaku seks ringan dan tidak ada yang memiliki perilaku seks berat dan dari 17 responden yang menggunakan sosial media dengan kurang baik terdapat 16 responden $(23,5 \%)$ memiliki perilaku seks berat dan hanya 1 responden $(1,5 \%)$ yang memiliki perilaku seks ringan.

Dari hasil uji Chi-square $\left(\chi^{2}\right)$, karena tidak ada nilai expected yang kurang dari 5 maka diperoleh nilai continuity correction 62,769 dan nilai $p$ Value $=0,000<\alpha=0,05$ berarti signifikan. Jadi Ho ditolak dan $\mathrm{Ha}$ diterima. Kesimpulannya ada hubungan yang signifikan antara penggunaan sosial media dengan perilaku seks bebas pada remaja kelas II SMKS 4 PGRI Kota Bengkulu tahun 2016.

Hasil uji contingency coefficient pada tabel diatas didapat nilai $\mathrm{C}=0,693$ dengan approx.sig. $=0.000 \leq 0.05$ berarti signifikan. Nilai $\mathrm{C}$ tersebut dibandingkan dengan nilai $C_{\max }=\sqrt{ }$ $\frac{m-1}{m}$ dimana $\mathrm{m}$ adalah nilai terkecil dari baris atau kolom. Nilai $\mathrm{C}_{\max }=\sqrt{ } \frac{2-1}{2}=$ 0.707. Karena nilai $C=0.693$ sangat dekat dengan nilai $\mathrm{C}_{\max }=0.707$, maka kategori hubungan sangat kuat. 
Tabel 7

Hubungan Peran Keluarga Dengan Perilaku Seks Bebas pada Remaja Kelas II di SMKS 4 PGRI Kota Bengkulu

\begin{tabular}{|c|c|c|c|c|c|c|c|c|c|}
\hline \multirow[b]{3}{*}{$\begin{array}{l}\text { Peran } \\
\text { keluarga }\end{array}$} & \multicolumn{4}{|c|}{ Perilaku Seks Bebas } & \multirow[b]{3}{*}{ Total } & \multirow[b]{3}{*}{$\%$} & \multirow[b]{3}{*}{$\chi^{2}$} & \multirow[b]{3}{*}{$p$} & \multirow[b]{3}{*}{$C$} \\
\hline & \multicolumn{2}{|c|}{ Berat } & \multicolumn{2}{|c|}{ Ringan } & & & & & \\
\hline & $\mathrm{N}$ & $\%$ & $\mathrm{~N}$ & $\%$ & & & & & \\
\hline Kurang & 16 & 23,5 & 6 & 8,8 & 22 & 32,4 & & & \\
\hline Baik & & & & & & & 43.748 & 0.000 & 0.626 \\
\hline Baik & 0 & 0,0 & 46 & 67,6 & 46 & 67,6 & & & \\
\hline Jumlah & 16 & 23,5 & 52 & 76,5 & 68 & 100,0 & & & \\
\hline
\end{tabular}

Tabulasi silang antara peran keluarga dengan perilaku seksual. Dari tabel tersebut diperoleh dari 46 responden yang memiliki peran keluarga dengan baik seluruhnya $(67,4 \%)$ memiliki perilaku seks ringan, dan dari 22 responden yang memiliki peran keluarga yang kurang baik terdapat 16 responden $(23,5 \%)$ memiliki perilaku seks berat dan 6 responden $(8,8 \%)$ memiliki perilaku seks ringan.

Dari hasil uji Chi-square $\left(X^{2}\right)$, karena tidak ada nilai expected yang kurang dari 5 maka diperoleh nilai continuity correction 43,748 dan nilai $p$ value $=0,000<\alpha=0,05$ berarti signifikan. Jadi Ho ditolak dan $\mathrm{Ha}$ diterima. Kesimpulannya ada hubungan yang signifikan antara peran keluarga dengan perilaku seks bebas pada remaja kelas II SMKS 4 PGRI Kota Bengkulu tahun 2016.

Hasil uji contingency coefficient pada tabel diatas didapat nilai $\mathrm{C}=0,626$ dengan approx.sig. $=0.000 \leq 0.05$ berarti signifikan. Nilai $\mathrm{C}$ tersebut dibandingkan dengan nilai $\mathrm{C}_{\max }=\sqrt{ }$ $\frac{m-1}{m}$ dimana $\mathrm{m}$ adalah nilai terkecil dari baris atau kolom. Nilai $\mathrm{C}_{\max }=\sqrt{ } \frac{2-1}{2}=$ 0.707. Karena nilai $\mathrm{C}=0.626$ sangat dekat dengan nilai $\mathrm{C}_{\max }=0.707$, maka kategori hubungan sangat kuat.

\section{Pembahasan}

Siswa dengan perilaku seks berat sebanyak 16 responden $(23,5 \%)$, dalam kategori ini kebanyakan dari mereka sudah berpacaran dan gaya berpacaran mereka sudah tergolong berat seperti berciuman dan bahkan ada yang sampai melakukan hubungan seks, sedangkan remaja dengan perilaku seks ringan yaitu 52 responden $(76,5 \%)$. Dalam penelitian ini, perilaku seks yang dilakukan oleh siswa SMKS 4 PGRI Kota Bengkulu yaitu berpegangan tangan dengan pacar dan juga teman mereka, menurut mereka itu adalah hal biasa. Hal tersebut masih tergolong perilaku seks bebas dengan kategori ringan.

Menurut Sarwono (2008) bentuk-bentuk dari perilaku seks bebas berat dapat berupa berkencan intim, berciuman, bercumbu, dan bersenggama sedangkan seks ringan berupa berpelukan, berpegangan tangan dan mencium kening. Sedangkan Desmita (2005) mengemukakan berbagai bentuk tingkah laku seksual dengan kategori berat seperti berkencan intim, bercumbu, sampai melakukan kontak seksual.

Penelitian lain yang mendukung diungkapkan oleh Darmasih (2009) bahwa bentuk perilaku seksual pranikah remaja SMA di Surakarta adalah melakukan berciuman bibir $81,6 \%$, masturbasi sebanyak 20,2\%. 
Perilaku seksual pranikah pada remaja SMA di Surakarta menunjukkan sebagian besar perilaku seks pranikah remaja dalam kategorik baik sebanyak $43,9 \%$, kategorik sedang sebanyak $40,4 \%$, dan kategorik buruk sebanyak $15,8 \%$.

Dari total 12 pernyataan tentang perilaku seks bebas, pernyataan nomor 12 yaitu apakah siswa menyukai teman sejenis memiliki skor terendah yaitu 0 (nol) itu artinya siwa di SMKS 4 PGRI Kota Bengkulu tidak ada yang melakukan perilaku seks menyimpang dengan menyukai teman sejenis mereka atau homoseks. Skor terendah kedua yaitu pernyataan nomor sembilan, hanya empat responden yang pernah mencium bibir teman lawan jenisnya.

Hasil penelitian tentang faktorfaktor yang mempengaruhi perilaku seks bebas pada remaja kelas II di SMKS 4 PGRI Kota Bengkulu menunjukkan bahwa kemampuan remaja dalam memahami dan mengetahui tentang perilaku seks bebas dan dampak dari perilaku seks bebas dalam kategori baik dengan persentase terbesar yaitu sebanyak 42 responden $(61,8 \%)$.

Dari total 10 (sepuluh) pertanyaan tentang pengetahuan perilaku seks, tiga pertanyaan dengan point terendah yaitu soal nomor tiga, empat dan soal nomor sepuluh. Pada soal nomor tiga yaitu bagaimana cara responden dalam menghindari dorongan seks tehadap teman atau lawan jenis kamu, kebanyakan dari responden menjawab menghindari sentuhan yang sifatnya merangsang dan menghindari berduaan ditempat sepi, padahal jawaban meningkatkan diri kepada Tuhan dan mendengarkan nasehat orang tua merupakan hal penting yang harus responden tahu, ini berarti pemahaman akan agama dan peran orang tua perlu ditingkatkan lagi. Pada soal nomor empat yaitu tentang dampak negatif yang muncul dari perilaku seksual yang tidak sehat, ratarata responden menjawab hanya berdampak pada kehamilan yang tidak diinginkan, sedangkan perasaan malu, bersalah dan minder merupakan dampak utama yang seharusnya timbul. Dan pada soal nomor sepuluh yaitu tentang dampak sosial yang timbul dari akibat melakukan perilaku seks, disini responden menjawab dikucilkan dan mendapat tekanan masyarakat, padahal dianggap wanita yang tidak bermoral jauh lebih penting, karena hal tersebut dapat berdampak pada gangguan kejiwaan.

Penggunaan sosial media pada remaja kelas II di SMKS 4 PGRI Kota Bengkulu dalam kategori baik sebanyak 51 responden (75,0\%), kebanyakan dari mereka menggunakan sosial media untuk menjalin komunikasi dengan teman-teman mereka terutama yang jarak tempat tinggal mereka tidak dalam satu wilayah. sedangkan dengan kategori kurang baik yaitu sebanyak 17 responden $(25,0 \%)$ menggunakan sosial media untuk mencari tahu apa itu seks bebas tanpa didampingi orang tua atau guru bahkan sengaja membuka media sosial untuk melihat gambargambar yang berbau pornografi.

Dari total sepuluh pernyataan tentang penggunaan sosial media, pernyataan dengan skor terendah yaitu terdapat pada pernyataan nomor sepuluh tentang pengetahuan seks yang didapatkan siswa dari sosial media mereka praktikkan dengan teman/pacar mereka, ini berarti penggunaan sosial media dalam hal mencari tahu tentang seks bebas hanya sebatas di sosial media saja. 
Peran keluarga yang baik pada remaja kelas II di SMKS 4 PGRI Kota Bengkulu yaitu sebanyak 46 responden $(67,6 \%)$ dimana keadaan keluarga atau situasi keluarga siswa dalam hal komunikasi dengan orang tua, orang tua yang tidak bercerai, dan remaja tinggal bersama orang tua semuanya terjalin dengan baik, sedangkan peran keluarga yang kurang baik yaitu sebanyak 22 responden $(32,4 \%)$ dimana mereka mengaku keluarga tidak terlalu berperan dalam setiap hal yang dilakukan baik disekolah maupun diluar sekolah, terutama kedua orang tua mereka yang sama-sama bekerja. Keluarga terutama orang tua adalah tokoh penting dalam perkembangan identitas remaja. Keluarga dapat membangun hubungan dan merupakan sistem dukungan ketika remaja menjajaki suatu dunia sosial yang lebih luas dan kompleks.

Dari total 20 pernyataan, skor pernyataan terendah terdapat pada dukungan penghargaan keluarga point ke satu, dua dan kelima, tentang keluarga yang harus tahu dengan siapa saja anaknya berteman, tentang memahami masalah yang dihadapi anaknya disekolah dan tentang dukungan keluarga mengenai kegiatan di sekolah.

Dari hasil penelitian terdapat 16 responden yang memiliki pengetahuan kurang baik, terdapat 3 responden yang berperilaku seks ringan. Hal ini disebabkan walaupun siswa memiliki pengetahuan yang kurang baik tentang perilaku seks bebas tetapi perilaku seksualnya tidak berat, hal tersebut dapat dipengaruhi oleh faktor lainnya seperti bimbingan dan pendidikan dari orang tua dirumah dengan baik. Sedangkan dari 42 responden yang memiliki pengetahuan yang baik, tidak ada responden yang berperilaku seksual berat. Ini menunjukkan bahwa siswa benar-benar menerapkan dengan baik ilmu pengetahuan tentang seks bebas yang didapat.

Berdasarkan uji statistik Pearson Chi-Square diperoleh hasil terdapat hubungan yang signifikan antara faktor pengetahuan dengan perilaku seksual pada siswa SMKS 4 PGRI Kota Bengkulu. Hal ini berarti semakin baik pengetahuan siswa maka perilaku seks bebas remaja di SMKS 4 PGRI Kota Bengkulu semakin baik. Sejalan dengan penelitian sebelumya yaitu Suryoputro (2006) dan Darmasih (2009) yang menyatakan bahwa pengetahuan tentang seks bebas berpengaruh terhadap perilaku seks pranikah pada remaja.

Secara teori pengetahuan dengan perilaku seks pranikah mempunyai hubungan yang positif, dimana semakin baik pengetahuan maka semakin rendah perilaku seksual bebas pada remaja. Apabila terjadi kontradiksi terhadap suatu faktor berarti ada faktor lain yang lebih besar yang mengendalikan faktor karena perilaku dipengaruhi oleh banyak hal (Suryoputro, 2006)

Sejalan juga dengan penelitian yang dilakukan oleh Fitrawati (2012) dengan judul "seks dan Seksualitas dikalangan siswa SMUN 9 Padang", Penelitian ini menemukan masih banyak remaja yang miskin informasi yang benar dan tepat tentang seks, seksualitas dan perilaku seksual. Sehingga pengetahuan dan pemahaman mereka masih ada yang tidak tepat, bahkan keliru mengenai seks, seksualitas dan perilaku seksual. Tindakan dan frekuensi perilaku seksual remaja juga sudah mengalami perubahan, dimana ditemukan tindakan yang sudah menjurus pada pergaulan bebas walaupun dari hasil penelitian ini tidak sampai melakukan hubungan badan. 
Sesuai dengan teori Suryoputro, (2006) yang menyatakan bahwa dengan pengetahuan yang baik maka perilaku seks bebas dapat dihindari. Secara teori pengetahuan dengan perilaku seks bebas mempunyai hubungan yang positif, dimana semakin baik pengetahuan maka semakin rendah perilaku seksual pada remaja. Apabila terjadi kontradiksi terhadap suatu faktor berarti ada faktor lain yang lebih besar yang mengendalikan faktor karena perilaku dipengaruhi oleh banyak hal.

Sedangkan menurut Amrillah (2006), bahwa semakin tinggi pengetahuan kesehatan reproduksi yang dimiliki remaja maka semakin rendah perilaku seksualnya, sebaliknya semakin rendah pengetahuan kesehatan reproduksi yang dimiliki remaja maka semakin tinggi perilaku seksualnya.

Berdasarkan hasil uji contingency coefficient, maka dalam penelitian ini dapat disimpulkan bahwa hubungan antara pengetahuan dengan perilaku seks bebas pada siswa SMKS 4 PGRI Kota Bengkulu dikategorikan hubungan sangat erat. Faktor-faktor yang mempengaruhi perilaku seksual yang dilakukan remaja tersebut secara garis besarnya disebabkan oleh faktor eksternal, yaitu faktor yang berasal dari luar individu seperti teman, lingkungan, orangtua dan pengaruh media massa. Sedangkan faktor internal yang merupakan faktor yang berasal dari individu sendiri dari hasil penelitian ini tidak terlalu berpengaruh.

Hasil penelitian menunjukkan dari 51 responden yang menggunakan sosial media dengan baik, tidak ada yang memiliki perilaku seks bebas berat. Hal ini dikarenakan responden memanfaatkan sosial media hanya sebagai media komunikasi, pencari informasi dalam hal pelajaran sekolah dan lebih berfokus kepada kesenangan dalam hal memiliki akun sosial seperti facebook, instagram dan twitter.

Kemudian dari 17 responden yang menggunakan sosial media dengan kurang baik, terdapat 16 siswa yang berperilaku seks bebas berat, hal ini diakibatkan oleh siswa menggunakan sosial media hanya sebagai sarana untuk mencari tahu tentang seks bebas yang awalnya secara tidak sengaja melihat konten/situs porno yang muncul dengan sendirinya di beberapa akun sosial media mereka kemudian berkembang dengan rasa ingin tahu tanpa bertanya dan didampingi oleh orang tua dan guru. Biasanya mereka menonton bersama teman-temannya disekolah dan diluar rumah baik melalui handphone, komputer maupun laptop. Sumber informasi yang diperoleh remaja lebih banyak diperoleh dari vidio di internet seperti youtube.

Berdasarkan uji statistik Pearson Chi-Square diperoleh hasil terdapat hubungan yang signifikan antara faktor sosial media dengan perilaku seksual pada siswa SMKS 4 PGRI Kota Bengkulu. Hal ini berarti semakin baik penggunaan sosial media pada siswa maka perilaku seks bebas remaja di SMKS 4 PGRI Kota Bengkulu semakin baik.

Berdasarkan hasil uji contingency coefficient, maka dalam penelitian ini dapat disimpulkan bahwa hubungan antara sosial media dengan perilaku seks bebas pada siswa SMKS 4 PGRI Kota Bengkulu dikategorikan hubungan sangat erat. Hasil penelitian ini sejalan dengan penelitian Sekarrini (2011) yaitu responden yang memiliki paparan terhadap media sosial, memiliki perilaku seksual yang berisiko berat sebesar $66,7 \%$, sedangkan responden yang tidak memiliki paparan terhadap media sosial memiliki perilaku seksual 
berisiko sebesar 40\%. Mohammad (1998) dalam Sekarrini (2011) menyatakan bahwa media sosial merupakan media yang paling banyak dipakai sebagai penyebarluasan media pornografi. Perkembangan hormonal pada remaja dipacu oleh paparan media sosial yang mengundang rasa ingin tahu dan keinginan untuk bereksperimen dalam aktifitas seksual. Sebagaimana dijelaskan oleh Bungin (2001) dalam Sekarrini (2011) sifat media sosial mengandung nilai manfaat, tetapi selain itu tidak sengaja menjadi media informasi yang mampu untuk menyebarkan nilai-nilai baru yang muncul di masyarakat. Media elektronik mempunyai peranan besar dalam memberikan informasi seksual, remaja yang belum pernah mengetahui masalah seksualitas dengan lengkap akan mencoba dan meniru apa yang mereka dengan dan lihat.

Untuk peneliti selanjutnya jika ingin meneliti kembali faktor sosial media sebaiknya lebih difokuskan ke situs yang lebih rawan akan pornografi atau dapat meneliti faktor media elektronik karena media elektronik merupakan media penyampai berita yang juga sering di gunakan para remaja.

Dari hasil penelitian didapat bahwa dari 46 responden yang memiliki peran keluarga yang baik, kesemuanya memiliki perilaku seks ringan. Dapat dinyatakan bahwa semakin tinggi peran keluarga pada remaja, maka perilaku seks bebas remaja semakin baik dan sebaliknya.

Hubungan orang tua yang harmonis akan menumbuhkan kehidupan emosional yang optimal terhadap perkembangan kepribadian remaja dan sebaliknya, orang tua yang sering bertengkar akan menghambat komunikasi dalam keluarga, dan remaja akan melarikan diri dari keluarga. Keluarga yang tidak lengkap misalnya karena perceraian, kematian, dan keluarga dengan keadaan ekonomi yang kurang, dapat mempengaruhi perkembangan jiwa remaja.

Menurut Soetjiningsih (2006), bahwa makin baik hubungan orang tua dengan anak remajanya, makin baik perilaku seksual bebas remaja. Hurlock (2004) berpendapat bahwa apabila orang tua merasa memiliki pengetahuan yang cukup mendalam tentang kesehatan reproduksi, remaja akan lebih yakin dan tidak merasa canggung untuk membicarakan topik yang berhubungan dengan masalah seks bebas.

Kemudian dari 22 responden yang memiliki peran keluarga yang kurang baik, terdapat 6 responden yang memiliki perilaku seks ringan, hal ini berarti walaupun siswa memiliki peran keluarga yang kurang baik, tetapi perilaku seks bebasnya ringan. Hal ini disebabkan pendidikan atau pengetahuan akan seks bebas sudah baik walau komunikasi antara siswa dengan keluarga kurang baik.

Menurut Syafrudin (2008), Dalam hal komunikasi orang tua dengan remaja, remaja seringkali merasa tidak nyaman atau tabu untuk membicarakan masalah seksualitas dan kesehatan reproduksinya.

Berdasarkan uji statistik Pearson Chi-Square diperoleh hasil terdapat hubungan yang signifikan antara faktor peran keluarga dengan perilaku seksual pada siswa SMKS 4 PGRI Kota Bengkulu. Hal ini berarti semakin baik peran keluarga terhadap siswa maka perilaku seks bebas remaja di SMKS 4 PGRI Kota Bengkulu semakin baik. Hasil penelitian diatas sesuai dengan penelitian Darmasih (2009), terhadap 114 responden menggunakan penguji dengan analisis regresi ganda ( multi regression) pada variabel menunjukkan 
pengaruh p-value $0,000<0,05$. Peran keluarga mempunyai pengaruh yang tinggi terhadap perilaku seksual pada remaja SMA di Surakarta. Di dukung oleh penelitian Suara, M (2011) bahwa responden yang memiliki keluarga yang tidak harmonis sebesar 39,2\% berisiko melakukan perilaku seksual pranikah dan yang memiliki keluarga hamonis sebesar 26,6\% tidak berisiko melakukan perilaku seksual pranikah.

Imanudin (1995) dalam Sarwono (2010) menyatakan bahwa orang tua mempunyai peran penting dalam proses sosialisasi anak. Dari orang tualah anak belajar tentang nilai-nilai dan sikap yang terdapat dan dianut masyarakat Menurut aliran psikoanalisis, orang - orang yang tidak mempunyai hubungan yang harmonis dengan orang tuanya dimasa keciE. maka kemungkinan besar akan menjadi orang yang paling sering melanggar norma masyarakat.

Berdasarkan hasil uji contingency coefficient, maka dalam penelitian ini dapat disimpulkan bahwa hubungan antara peran keluarga dengan perilaku seks bebas pada siswa SMKS 4 PGRI Kota Bengkulu dikategorikan hubungan sangat erat. Wicaksono dalam Setiawan (2008) menyatakan bahwa seringnya orang tua bertengkar serta perceraian orang tua oleh karena itu remaja ingin mengalihkan kejenuhan dengan perilaku menyimpang dengan melakukan hubungan seks. Wahyurini dan Ma'shum dalam Afiah (2007) menyatakan bahwa kondisi keluarga yang harmonis ditandai oleh suatu bentuk komunikasi yang baik antara suami dan istri, orang tua dengan anak dan anak dengan saudaranya. Komunikasi yang harmonis antara suami dan istri mencegah terjadinya perceraian antara keduanya. Hal ini dapat mengurangi kemungkinan anak berbagi cerita dengan orang lain karena memiliki orangtua yang lengkap. Pendidikan orang tua juga berpengaruh terhadap keharmonisan keluarga. Namun kurangnya komunikasi secara terbuka antara orang tua dengan remaja dalam masalah seksual dapat memperkuat munculnya perilaku seksual.

Untuk penelitian selanjutnya jika ingin meneliti faktor peran keluarga sebaiknya dapat meneliti dari segi keterlibatan orang tua saja tidak ditikberatkan kepada peran saudara, karena orang tua merupakan role mode bagi anaknya, dan bagi peneliti selanjutnya bisa meneliti faktor lingkungan atau juga bisa faktor religius.

\section{Kesimpulan}

1. Ada 52 responden $(76,5 \%)$ memiliki perilaku seks ringan.

2. Ada 42 responden $(61,8 \%)$ memiliki pengetahuan yang baik tentang perilaku seks bebas.

3. Ada 51 responden $(75,0 \%)$ menggunakan sosial media dengan baik.

4. Ada 46 responden $(67,6 \%)$ memiliki peran keluarga yang baik.

5. Ada hubungan yang signifikan antara pengetahuan dengan perilaku seks bebas pada remaja kelas II di SMKS 4 PGRI Kota Bengkulu dengan kategori hubungan sangat kuat.

6. Ada hubungan yang signifikan antara sosial media dengan perilaku seks bebas pada remaja kelas II di SMKS 4 PGRI Kota Bengkulu dengan kategori hubungan sangat kuat.

7. Ada hubungan yang signifikan antara peran keluarga dengan perilaku seks bebas pada remaja kelas II di SMKS 4 PGRI Kota 
Bengkulu dengan kategori hubungan sangat kuat

\section{Daftar Pustaka}

Arikunto, S. (2010). Metodologi Penelitian Kesehatan. Jakarta : Rineka Cipta.

Arudo, T.O. (2008). Peer Counseling Exsperience Among Selected Kenyan Secondary School. Paper dalam KAPC Conference 2-8 September 2003 di Safari Park Hotel, Kenya

BKKBN. (2011). Detail Rubrik. diakses 6 februari 2011, dari www.bkkbn.go.id/Webs.

Chyntia. (2003). Pendidikan seks. http://www.scribd.com.dok//Pe ndidikanseks

Dianawati. 2007 . Peran Biopsikososial terhadap Perilaku Seksual Beresiko Tertular HIV pada Remaja SLTA di DKI Jakarta 2006. Disertasi. Depok Jakarta : Pasca Sarjana Universitas Indonesia.

Kedaulatan Rakyat. 2007. Education and Prevention Program for HIV/AIDS. FHI, USAID-The AIDS Control \& Prevention (AIDSCAP). Project Report. Jakarta: Ministry of Education.
Kementerian Kesehatan RI. 2010. Profil Kesehatan Indonesia. Penerbit Direktorat Yan. Kep. Dirjen Yan. Med : Jakarta.

Komisi Nasional Perlindungan Anak. 2009. Catatan Akhir Tahun 2009 Pelanggaran Hak Anak Terus Meningkat. Jakarta.

Mussen. 2007. Bicara Soal Cinta, Pacaran, dan Seks kepada Remaja: Panduan Guru dan Orang Tua. Jakarta: Esensi.

Notoatmodjo, S (2008). Konsep dan Penerapan Metodologi Penelitian ilmu Keperawatan.Salemba Medika : Jakarta. (2010). Metodologi Penelitian Kesehatan. Rineka Cipta : Jakarta.

Santrock, J.W. 2009. Educational Psychology Fourth Edition. New York: MC Graw-Hill.

Sebayang. 2010. Pengaruh Pendidikan Kesehatan Seksual Terhadap Pengetahuan dan Sikap Remaja dalam Upaya Pencegahan HIV/AIDS di Kodya Yogyakarta. UGM : Yoyakarta.

Soetjiningsih. 2006. Remaja 15-18 tahun banyak lakukan seks pranikah. Terdapat pada : http://www.ugm.ac.id./index.ph $\mathrm{p}$ ? 